\title{
MOLECULAR CHARACTERIZATION OF CONTRACAECUM RUDOLPHII HARTWICH, 1964 (NEMATODA: ANISAKIDAE) FROM THE CORMORANT PHALACROCORAX CARBO IN IRAQ
}

\author{
Amjed Qays Alqaisi* Harith Saeed Al-Warid * \\ and \\ Azhar A. Al-Moussawi** \\ *Department of Biology, College of Science, University of Baghdad, \\ Baghdad, Iraq \\ ** Iraq Natural History Research Center and Museum, University of \\ Baghdad, Baghdad, Iraq \\ -corresponding author e-mail: amjeddurham@gmail.com; \\ amjed.alqaisi@sc.uobaghdad.edu.iq
}

Received Date: 22 June 2020, Accepted Date: 13 August 2020, Published Date: 21 December 2020

\section{ABSTRACT}

Contracaecum rudolphii Hartwich, 1964 is a nematode which causes major concerns to human and wildlife animal's health. However, the population genetics of C. rudolphii has been poorly studied in Iraq. In order to gain a deeper understanding in the outline of the genetic diversity of the nematode $C$. rudolphii that were isolated from its host cormorant Phalacrocorax carbo (Linnaeus, 1758), in the middle areas of Iraq, twenty specimens of $C$. rudolphii adults were isolated from nine individuals of $P$. carbo. The first (ITS-1) internal transcribed spacers (ITS) of ribosomal DNA (rDNA) of $C$. rudolphii were amplified using conventional polymerase chain reaction (PCR); then, the amplicons were subjected to sequencing. Concatenation of ITS-1 (rDNA) sequences resulted in four unique genotypes that have not been previously recorded in Iraq. The present study showed that the most common genotype occurred in $85 \%$ of C. rudolphii, and in $88.9 \%$ of cormorants. Furthermore, the infrapopulation difference in the genotypes was fairly high, with an average of $1.3 \pm 0.48$ genotypes per host of those with $\geq$ two nematodes. All the sequences of the current study were distributed into two different populations. The sequences of ITS-1 for the first population had the highest similarity to ITS-1 sequence of C. rudolphii B, while the sequences of ITS-1 for the second population had the highest similarity to ITS-1 sequence of C. rudolphii A. This study provides an insight about the genetic divergence of $C$. rudolphii among $P$. carbo in Iraq. As well, the results likely support the hypothesis that $C$. rudolphii represents a complex of at least two sibling species.

Keywords: Contracaecum rudolphii, GenotypeITS-1, Iraq, Phalacrocorax carbo, Polymerase chain reaction (PCR). 


\section{INTRODUCTION}

The roundworm Contracaecum rudolphii Hartwich, 1964 (Nematoda: Anisakidae) is a parasitic intestinal nematode of the cormorants, pelicans, and ducks (Moravec, 2009). It is considered to have highly pathogenic effects on both wildlife and humans (Shamsi, 2009). In many regions, the species is progressively identified as an emerging concern for human health. The larvae of Contracaecum spp. are the causative agent of human Anisakidosis (Shamsi, 2014). Several reports have revealed that the larvae cause a severe and painful condition in humans following ingestion of under-cooked fish carrying third stage larvae of Contracaecum species including C. rudolphii (Takabayashi et al., 2014; Bookhout and Greene, 2019). C. rudolphii like to most other anisakid is transmitted through many hosts. The first intermediate hosts of $C$. rudolphii are crustaceans and larvae of aquatic insects; fish regards the second intermediate or paratenic hosts, while fishing birds are the final hosts (Bartlett, 1996; Dziekońska-Rynko and Rokicki, 2007). Anthropogenic shifts to natural landscapes have resulted in significant increases in population densities of wildlife species in some areas (Daszak et al., 2001; Barrueto et al., 2014). Such increases in the number of wildlife species are likely to increase the occurrence of $C$. rudolphii and promote extra transmission of $C$. rudolphii between birds and fish, also fish and humans (Kanarek, 2011).

The genetic variability of $C$. rudolphii is poorly investigated, regardless of the fact that discriminating the genetic population has significant consequences to considerate the evolutionary ecology of the species, and can give some important information for controlling the parasite in humans and wildlife animals (Shamsi et al., 2009; Cole and Viney, 2018). A previous study on $C$. rudolphii illustrated that the first (ITS1) and/or second (ITS-2) internal transcribed spacers (ITS) of ribosomal nuclear DNA (rDNA) provide genetic markers for the specific identification of number of ascaridoid species (Szostakowska and Fagerholm, 2012). In addition, some studies have shown that sibling species can be identified and distinguished based on of ITS-1 and/or ITS-2 (Zhu et al., 2000; Mattiucci et al., 2003; Li et al., 2005). Yet the broader of the molecular characterization and genetic polymorphism of $C$. rudolphii was not the topic of focused work in Iraq, although ITS-1 was used in one study from Thi-Qar southern of Iraq to identify the fourth-stage larvae of Contracaecum microcephalum (Rudolphi, 1809) and C. septentrionale (Kreis, 1955) which were isolated from proventriculus of Nycticorax nycticorax (Linnaeus, 1758) in Al-Sanaf marsh, southern of Iraq by Mohammad and Hbaiel (2019 a). Moreover, C. rudolphii has been morphologically identified and recorded recently by Al-Moussawi and Mohammad (2011); Al-Moussawi (2017) and Mohammad and Hbaiel (2019 b).

The purpose of the current study is to quantify the genetic divergence of $C$. rudolphii Hartwich, 1964 from the P. carbo (Linnaeus, 1758) in Iraq.

\section{Collection of parasites}

\section{MATERIALS AND METHODS}

Adult nematodes were collected from nine infected $P$. carbo obtained from trappers that were collected from Tarmiyah district $\left(33.6732^{\circ} \mathrm{N}, 44.3615^{\circ} \mathrm{E}\right)$, Baghdad province, central Iraq (Map 1), for an unrelated project (Al-Moussawi, 2017). The cormorants were identified according to Allouse (1961) and Salim et al. (2009), the sex of each was recorded; they were dissected, and the digestive tracts were opened and searched for nematodes. Adult nematodes were collected, cleared with lactophenol and identified microscopically. The identification of 
the adult nematode was based on the characteristic features collected from different works (York and Maplestone, 1962; Amato et al., 2006; D'Amelio et al., 2012; Moravec and Scholz, 2016; Al-Moussawi, 2017). The diagnostic features of the anterior end (cephalic extremity of the nematode) such as the presence of labia, interlabia and interlabial bifurcation in the base were considered for identification. The main identification features in males are the number of spicules, the shape of each spicules tip, the number and distribution of papillae on the tail, number of precloacal and postcloacal papillae. In females, the main identification features are the distance of vulva from the anterior and posterior ends, and the shape of the tail. The identification of the specimens was based on the previously mentioned criteria of $C$. rudolphii, regardless of the morphometric measurements. The identifying of all specimens were conducted by the third author. The morphometric measurements were not considered in this study.

All nematodes were counted, preserved in $70 \%$ ethanol $(\mathrm{v} / \mathrm{v})$ and kept at room temperature prior DNA extraction; the sex of each nematode was identified under a dissecting microscope. Representative voucher specimens of $C$. rudolphii were deposited in the Iraq Natural History Research Center and Museum, University of Baghdad. From the pool of the adult nematodes removed from the nine infected cormorant specimens (eight males and one female), 20 (eight males and 12 females) adult worms were selected for genetic analyses. The number of analyzed nematodes differed among cormorant individuals. For heavily parasitized hosts, a maximum of five nematodes were selected for genotyping, while all collected nematodes were genotyped for hosts with one, two or three parasites. This study protocol was approved by the local ethics committee (Ref.: BEC/1019/0015), in Department of Biology, College of Science, University of Baghdad.

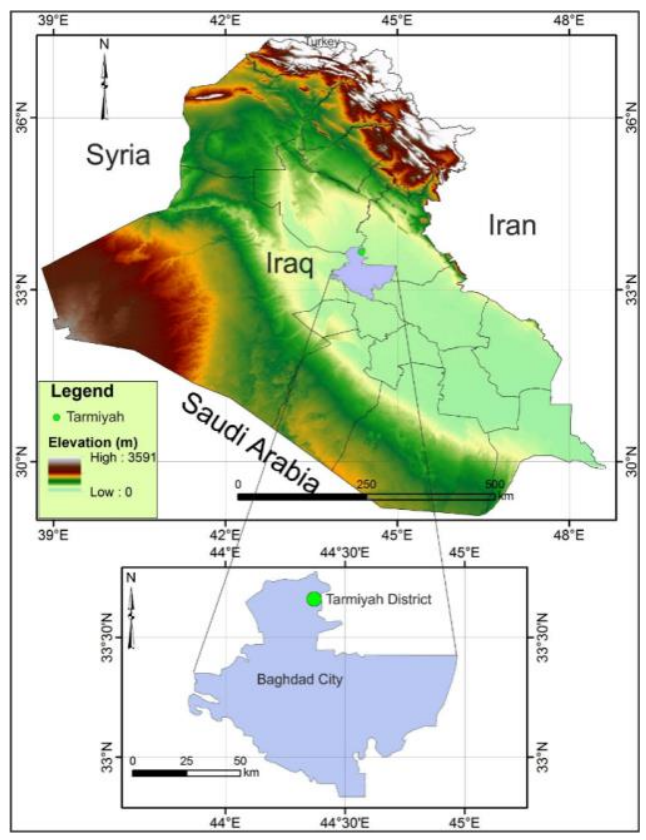

Map (1): Map of study site in the central Iraq, Tarmiyah district, Baghdad province. (The map was processed using ArcGIS 10.3.1 software) 
Table (1): Gene Bank accession numbers of the twenty Contracaecum rudolphii isolated from nine Cormorants collected in Tarmiyah district, Baghdad province $\left(33.6732^{\circ}\right.$ $\left.\mathrm{N}, 44.3615^{\circ} \mathrm{E}\right)$, central Iraq.

\begin{tabular}{|c|c|c|c|c|c|}
\hline \multicolumn{2}{|c|}{ Host } & \multicolumn{4}{|c|}{ Nematodes } \\
\hline ID & Sex & $\begin{array}{l}\text { Number of } \\
\text { specimens }\end{array}$ & $\begin{array}{c}\text { GenBank } \\
\text { accession number }\end{array}$ & Sex & Genotype \\
\hline \multirow[t]{2}{*}{$\mathrm{C} 1$} & \multirow[t]{2}{*}{ Female } & \multirow[t]{2}{*}{2} & MT308989 & Female & G4 \\
\hline & & & МТ308991 & Male & G4 \\
\hline $\mathrm{C} 2$ & Male & 1 & MT012368 & Female & G2 \\
\hline \multirow[t]{5}{*}{$\mathrm{C} 3$} & \multirow[t]{5}{*}{ Male } & \multirow[t]{5}{*}{5} & MT308990 & Female & G4 \\
\hline & & & MT308999 & Female & G4 \\
\hline & & & MT012369 & Male & G3 \\
\hline & & & МТ308994 & Male & G4 \\
\hline & & & MT308998 & Male & G4 \\
\hline \multirow[t]{3}{*}{$\mathrm{C} 4$} & \multirow[t]{3}{*}{ Male } & \multirow[t]{3}{*}{3} & MT308997 & Female & G4 \\
\hline & & & MT309003 & Female & G4 \\
\hline & & & МТ308993 & Male & G4 \\
\hline C5 & Male & 1 & MT309002 & Female & G4 \\
\hline \multirow[t]{2}{*}{ C6 } & \multirow[t]{2}{*}{ Male } & \multirow[t]{2}{*}{2} & MT308996 & Female & G4 \\
\hline & & & MT308992 & Male & G4 \\
\hline \multirow[t]{2}{*}{ C7 } & \multirow[t]{2}{*}{ Male } & \multirow[t]{2}{*}{2} & MT309000 & Female & G4 \\
\hline & & & MT308995 & Male & G4 \\
\hline \multirow[t]{2}{*}{$\mathrm{C} 8$} & \multirow[t]{2}{*}{ Male } & \multirow[t]{2}{*}{2} & MT308988 & Female & G4 \\
\hline & & & MT309001 & Male & G4 \\
\hline \multirow[t]{2}{*}{ C9 } & \multirow[t]{2}{*}{ Male } & \multirow[t]{2}{*}{2} & MT012366 & Female & G4 \\
\hline & & & MT012367 & Female & G1 \\
\hline
\end{tabular}

\section{DNA extraction and amplification}

Total genomic DNA was extracted using ABIOpure TM Total DNA kit (ABIOpure, USA) following manufacturer's instructions. A thermal cycler was used to amplify segments of ITS1 from each specimen by using the conventional PCR. The forward primer 5 GGCTTATGGCTTGCTGTGTG-3`and reverse primer 5`CGCCCGCATATCCAAGAATG3, were used. The primers were designed by using Pick primer tool found within NCBI GenBank. Many genes were used as reference genes for these primers, the NCBI GenBank accession numbers for these reference genes are AJ634783.1, MN557377.1, MN557376.1, MK424808.1, MK424807.1, MK424806.1, MK424801.1, MK424800.1, MK161411.1, MK161410.1， MK161409.1， MK161408.1， JQ071409.1， JQ071406.1， JQ071404.1， JQ071398.1, JQ071395.1, JQ071394.1, JQ071393.1, JF424597.1, FM210432.1, FM210251.1, FM177542.1, FJ467620.1, FJ467618.1, DQ316968.1, AY821753.1, AY821752.1 and AY821751.1. The primer melting temperature (Tm) for forward primer is $59.83^{\circ} \mathrm{C}$, while the Tm for reverse primer is $59.48^{\circ} \mathrm{C}$.

Thirty cycles of amplification in an Eppendorf thermocycler were following the program of denaturation at $95^{\circ} \mathrm{C}$ for 30 second, annealing at $65^{\circ} \mathrm{C}$ for 30 second, and extension at $72^{\circ} \mathrm{C}$ for 30 second. An initial denaturation step consisting of incubation at $95^{\circ} \mathrm{C}$ for $5 \mathrm{~min}$ and a final extension step consisting of incubation at $72^{\circ} \mathrm{C}$ for $7 \mathrm{~min}$ were also added. After PCR 
amplification, all the samples were separated on $1 \%$ agarose. Gels were run using OWL Electrophoresis System (thermos, USA), in 1X TBE buffer (Tris-acetate EDTA); samples of DNA were mixed with $1 / 10$ volume of loading buffer and loaded into the wells on the gel. TBE was added to cover the gel and run for $75 \mathrm{~min}$ at $100 \mathrm{v} / \mathrm{m}$ Amp. The gel was stained with ethidium bromide $1 \mu \mathrm{l} / \mathrm{ml}$. DNA bands were visualized using Gel imaging system (Major Science, Taiwan).

\section{Sequencing and sequence analysis}

The PCR products were sent for Sanger sequencing using ABI3730XL, automated DNA sequencer, by Macrogen Corporation - Korea. The results were received by email and then analyzed using genious software. Nucleotide sequence data reported in this paper are available in the GenBank database under the accession numbers MT012366 to MT012369 and the accession numbers MT308988 to MT309003 (Tab. 1). For each sequence, the NCBI Blast program was used for homology search (http://www.ncbi.nlm.nih.gov/).

\section{Phylogenetic analysis}

Phylogenetic tree was constructed using the PhyML program which is hosted at the http://www.phylogeny.fr/simple_phylogeny.cgi website; gene sequences were aligned by MUSCLE alignment (Edgar, 2004) and the curation for the aligned sequences was achieved using Gblocks. Then, the tree was constructed using PhyML program with the application of specific parameters; the model used for constructing the tree was General time-reversible (GTR) and the starting tree was constructed using Bio neighbor-joining (NJ). The tree topology and branch length were adjusted simultaneously using a hill-climbing algorithm and a fast distance-based method was used to draw the trees with modification of the tree to improve its likelihood at each iteration (Guindon et al., 2010). A tree in the Newick format, the output of PhyML program, was submitted to FigTree v1.4.2 (http://tree.bio.ed.ac.uk/software/figtree/) for the purpose of visualization and coloring of the strains and the branches. The tree was constructed to analyze the phylogenetic relationship among the twenty sequences of $C$. rudolphii in the present study (Tab. 1), as well as to analyze the phylogenetic relationship of these sequences with additional more sequences of related species with adequate geographic coverage (Tab. 2).

\section{Statistical analyses}

The obtained results were stated as percentage and mean \pm standard deviation (SD). Data analysis was done by SPSS 16.0 (SPSS Inc., Chicago, IL, USA). The data were assessed by chi-square test. The genetic diversity between populations was assessed used ANOVA. P values $<0.05$ were considered statistically significant.

\section{Morphological identification}

\section{RESULTS}

Morphological examinations revealed that all the examined nematodes in the present study had the most typical features of the adult $C$. rudolphii. There were no significant morphological differences of $C$. rudolphii among the individual worms; all were found to share most of the morphological characters with very minor differences among them. Body of the adults of $C$. rudolphii is yellowish, coiled, covered with a striated cuticle and tapering at its two ends. Head small, with three triangular interlabia, which are wider at their base; and three, one dorsal and two sub ventral, round, large and equal in size labia, each of them bear 
two oval cephalic papillae on their dorsal sides. The excretory pore locates at the base of interlabium. Lips followed immediately by fine dense annulations of the collar area. Oesophagus is muscular, cylindrical, followed by short globular ventriculus connected to a posterior ventricular appendix. Tail conical and pointed at its end. The male has 2 equal spicules; the shape of the spicule, the groove along spicule length, and the shape of the tip are the characteristic features for this species. Females are larger than males, vulva in the anterior third of the body, tail longer than in males.

\section{PCR ITS-1, Sequence and phylogenetic analyses}

The ITS-1 (309 bp) amplicons from individual C. rudolphii $(\mathrm{n}=20)$ represented single bands on agarose gels. Examination of ITS-1 sequences (309 bp) revealed four unique Genotypes: G1, G2, G3 and G4 (Accession \#MT012367, \# MT012368, \# MT012366 and \# MT012367) respectively. The most common genotype is G4 occurred in 17 of the $20(85 \%)$ C. rudolphii, and in eight of the nine (88.9\%) of $P$. carbo, while the other genotypes (G1, G2 and G3) were found only once (Tab. 2). Out of the seven birds parasitized with mean intensity of more than one, only two (28.6\%) were parasitized with individuals having different genotypes. Results also showed that there was an average $( \pm \mathrm{SD})$ of $1.3 \pm 0.48$ genotypes per host for the seven cormorants with $\geq$ two analyzed nematodes. The proportion of genotypes did not differ significantly by nematode sex $\left(X^{2}=3.363\right.$, d.f. $\left.=3, p=0.33\right)$. Co-occurring males and females of $C$. rudolphii were identified in six specimens of $P$. carbo. In two of those cases, more than one genotypes were detected, indicating that at least one of the $C$. rudolphii in these individual hosts was maternally unrelated. Pairwise comparisons of nucleotide sequences among the four genotypes of $C$. rudolphii showed differences of 2.1-3.8\% (ITS-1). Comparison among all sequences showed 26 variations in nucleotides. Of these, 17 (65.4\%) were single-base substitutions, of which seven $(41.2 \%)$ were intermediate changes between either the purines $(\mathrm{A}<->\mathrm{G} ; \mathrm{n}=4)$ or the pyrimidines $(\mathrm{C}<->\mathrm{T} ; \mathrm{n}=3)$ and $10(58.2 \%)$ were transversions (substitutions between a purine and a pyrimidine), although 9 variations (34.6 $\%$ ) related to the events of deletion / insertion.

The phylogenetic relationship among the 20 isolates of $C$. rudolphii in the present study and additional more sequences of related species (Tab. 3) with adequate geographic coverage were illustrated in Diagram (1) and Table (4). All the sequences of the current study ( $n=20$; genotypes $n=4$ ) were distributed in two different populations the first one (Population I) is the cluster of G2 and G4 population (mean of genetic diversity $=0.007 \pm 0.0013$ ) and the second (Population II) is the cluster of G1 and G3 population (mean of genetic diversity $=0.018 \pm 0.0089$ ) (Tab. 4). Significant difference was noticed between the means of genetic diversity of these two populations $(\mathrm{F}=36.17, \mathrm{P}=0)$. Interestingly, as shown in Diagram (1), the two isolates of the first population (Accession \#MT012367 and \#MT012369) are closely clustered to $C$. septentrionale (Accession \#MK424799) that isolated from night heron Nycticorax nycticorax (Linnaeus, 1758) in Thi-Qar, Iraq by Mohammad and Hbaiel (2019 a), while the genotypes present in that population were dispersed, with $C$. microcephalum (Accession \#MK424795) that was isolated from N. nycticorax in Thi-Qar, Iraq (Mohammad and Hbaiel, 2019 a). Furthermore, the sequences of Contracaecum sp. isolated from fish collected from Parishan Lake, Islamic republic of Iran (Shamsi and Aghazadeh-Meshgi, 2011) and Lake Nasser, Egypt (Younis et al., 2017) were highly dispersed, and no obvious correlations of close clusters were noticed with the two populations presented in the current study. The Blast analyses (Tab. 5) revealed that sequences of ITS-1 
for each G2 and G4 (represented population I) had the highest similarity (97.83\%) to ITS-1 sequence of $C$. rudolphii B (Accession\# JQ071394 and \#AJ634783), while the sequences of ITS-1 for each G1 and G3 (represented population II) had the highest similarity $(98.55 \%$ and 98.20\%) respectively to ITS-1 sequence of C. rudolphii A (Accession\# JQ071414). Moreover, sequences of ITS-1 for each of G2 and G4 (represented population I) had the less similarity (96.74\%) and (96.81\%) to ITS-1 sequence of C. rudolphii F (Accession\# JF424597), and the sequences of ITS-1 for each of G1 and G3 (represented Population II) had the less similarity (96.46\% and 96.73\%) to ITS-1 sequence of C. rudolphii F (Accession\# JF424597). The phylogenetic relationship among the twenty isolates of $C$. rudolphii in the present study and additional more published sequences of $C$. rudolphii A, B and F were illustrated in Diagram (2). Results showed that population I (G2 and G4) are highly related to C. rudolphii B, while population II (G1 and G3) are highly related to C. rudolphii A. The identities and phylogenetic distances of the selected and most related ITS sequences showed that the isolates of $C$. rudolphii analyzed in this study are likely related to two species $C$. rudolphii A and B.

Table (2): Distribution of nuclear genotypes of C. rudolphii identified in nine Cormorants from Tarmiyah district, Baghdad province $\left(33.6732^{\circ} \mathrm{N}, 44.3615^{\circ} \mathrm{E}\right)$, central Iraq.

\begin{tabular}{|c|c|c|c|c|c|c|c|}
\hline \multicolumn{2}{|c|}{ Host } & \multicolumn{2}{c|}{ Nematodes } & \multicolumn{4}{c|}{ Genotypes } \\
\hline ID & Sex & Analyzed & Sex (M:F) & G1 & G2 & G3 & G4 \\
\hline C1 & Female & 2 & $(1: 1)$ & 0 & 0 & 0 & 2 \\
\hline C2 & Male & 1 & $(0: 1)$ & 0 & 1 & 0 & 0 \\
\hline C3 & Male & 5 & $(3: 2)$ & 0 & 0 & 1 & 4 \\
\hline C4 & Male & 3 & $(1: 2)$ & 0 & 0 & 0 & 3 \\
\hline C5 & Male & 1 & $(0: 1)$ & 0 & 0 & 0 & 1 \\
\hline C6 & Male & 2 & $(1: 1)$ & 0 & 0 & 0 & 2 \\
\hline C7 & Male & 2 & $(1: 1)$ & 0 & 0 & 0 & 2 \\
\hline C8 & Male & 2 & $(1: 1)$ & 0 & 0 & 0 & 2 \\
\hline C9 & Male & 2 & $(0: 2)$ & 1 & 0 & 0 & 1 \\
\hline Total & & 20 & $(8: 12)$ & 1 & 1 & 1 & 17 \\
\hline
\end{tabular}

Table (3): Host, location and GenBank accession number of sequences of the related species with adequate geographic coverage.

\begin{tabular}{|c|c|c|c|c|}
\hline Taxa & Host & Location & $\begin{array}{c}\text { GenBank } \\
\text { accession } \\
\text { number }\end{array}$ & References \\
\hline Contracaecum sp. & Barboid fishes & $\begin{array}{l}\text { Parishan } \\
\text { Lake, the } \\
\text { largest } \\
\text { freshwater } \\
\text { lake in } \\
\text { Iran. }\end{array}$ & $\begin{array}{l}\text { FM210435 } \\
\text { FM210434 } \\
\text { FM210433 }\end{array}$ & $\begin{array}{c}\text { Shamsi and } \\
\text { Aghazadeh- } \\
\text { Meshgi } \\
(2011)\end{array}$ \\
\hline Contracaecum sp. & $\begin{array}{l}\text { Oreochromis niloticus } \\
\text { (Linnaeus, 1758); } \\
\text { Tilapia galilaea } \\
\text { (Linnaeus, 1758); Lates } \\
\text { niloticus (Linnaeus, }\end{array}$ & $\begin{array}{c}\text { Lake } \\
\text { Nasser, } \\
\text { Egypt }\end{array}$ & $\begin{array}{l}\text { KX580602 } \\
\text { KX580603 } \\
\text { KX580604 } \\
\text { KX580605 } \\
\text { KX580606 }\end{array}$ & $\begin{array}{l}\text { Younis et al. } \\
\quad(2017)\end{array}$ \\
\hline
\end{tabular}


Molecular characterization of Contracaecum rudolphii

\begin{tabular}{|c|c|c|c|c|}
\hline & $\begin{array}{c}\text { 1758); Synodontis } \\
\text { frontosus Vaillant, } \\
\text { 1895; Mormyrus } \\
\text { caschive Linnaeus, } \\
\text { 1758; Chrysichthys } \\
\text { Auratus (Geoffroy } \\
\text { Saint-Hilaire, 1809); } \\
\text { Hydrocynus forskahlii } \\
\text { (Cuvier, 1819); Alestes } \\
\text { Baremose (Joannis, } \\
\text { 1835); and Labeo } \\
\text { niloticus (Linnaeus, } \\
\text { 1758) }\end{array}$ & & KX580607 & \\
\hline C. rocephalum & Nycticorax nycticorax & $\begin{array}{c}\text { Thi-Qar, } \\
\text { Iraq }\end{array}$ & MK424795 & $\begin{array}{c}\text { Mohammad } \\
\text { and Hbaiel } \\
(2019 \text { a) }\end{array}$ \\
\hline C. septentrionale & Nycticorax nycticorax & $\begin{array}{c}\text { Thi-Qar, } \\
\text { Iraq }\end{array}$ & MK424799 & $\begin{array}{l}\text { Mohammad } \\
\text { and Hbaiel } \\
\text { (2019 a) }\end{array}$ \\
\hline
\end{tabular}

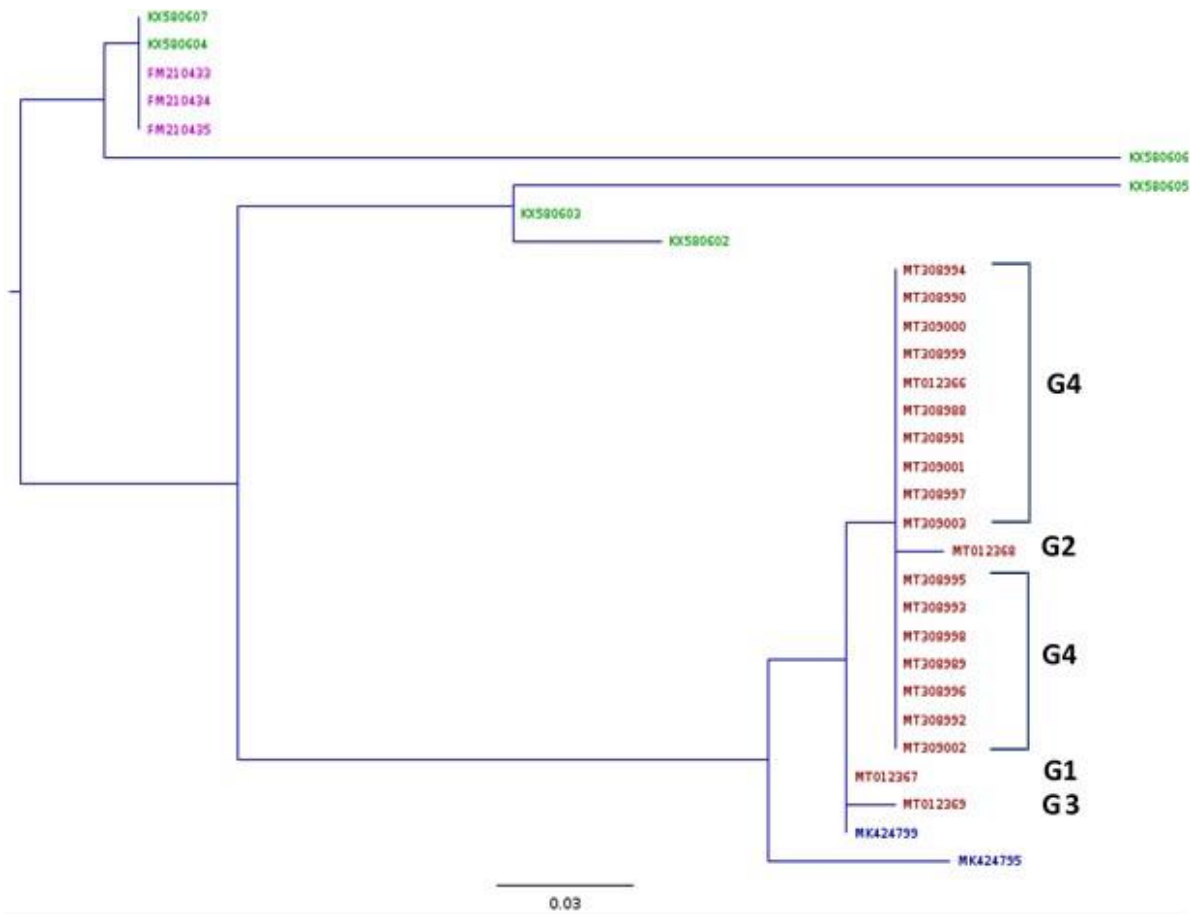

Diagram (1): Phylogenetic tree of the aligned 31 ITS-1 sequences from Contracaecum spp. including 20 ITS-1 sequences of $C$. rudolphii, identified in this study using the PhyML program which is hosted at the http://www.phylogeny.fr/simple_phylogeny.cgi website. 
Table (4): The two populations of $C$. rudolphii identified in nine Cormorants from Tarmiyah district, Baghdad province $\left(33.6732^{\circ} \mathrm{N}, 44.3615^{\circ} \mathrm{E}\right)$, central Iraq.

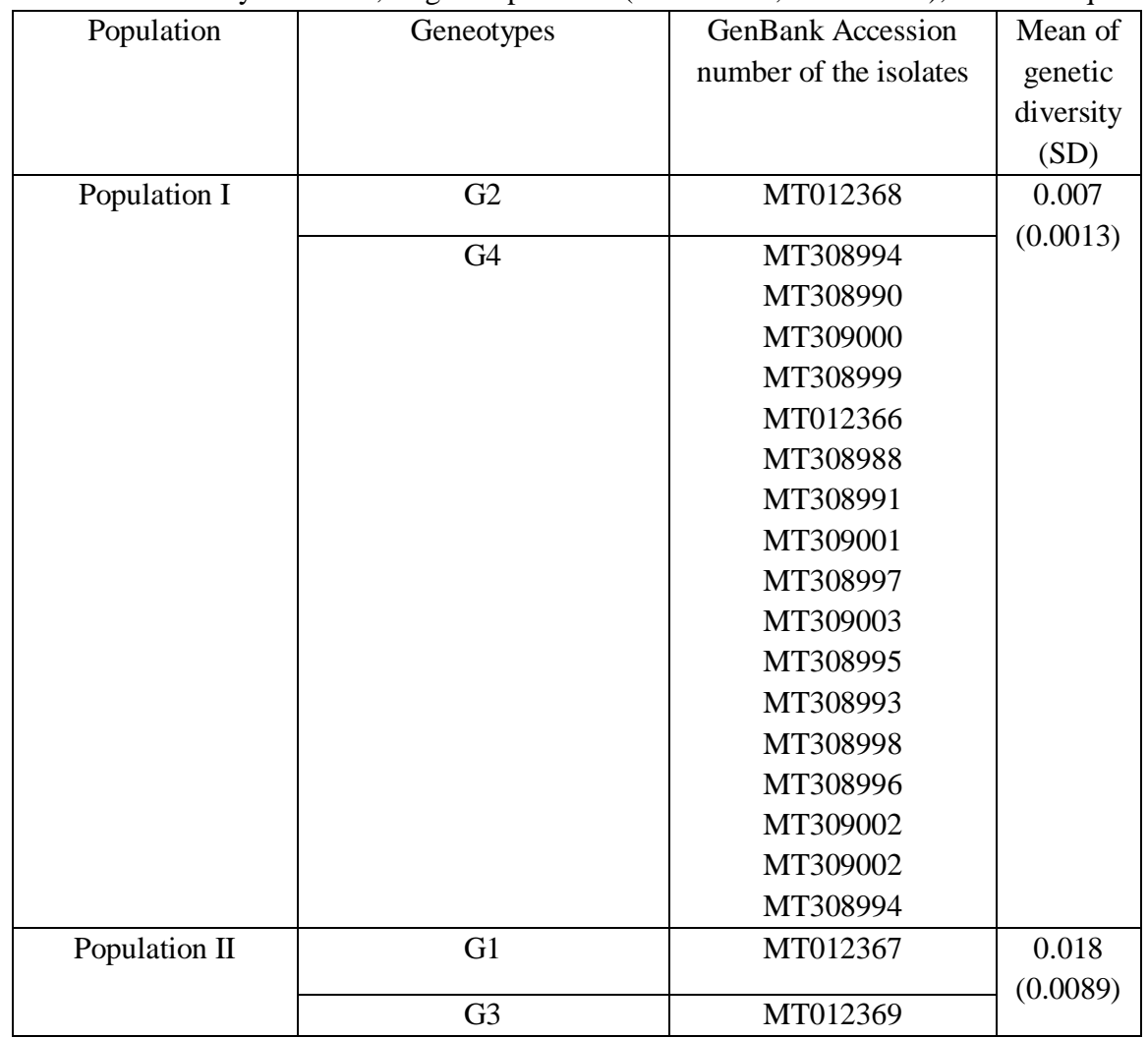

Table (5): The two populations of $C$. rudolphii identified in nine Cormorants from Tarmiyah District $\left(33.6732^{\circ} \mathrm{N}, 44.3615^{\circ} \mathrm{E}\right)$, central Iraq and their identity to some $C$. rudolphii isolates from NCBI GenBank.

\begin{tabular}{|c|c|c|}
\hline $\begin{array}{l}\text { Genotype } \\
\text { (Population) }\end{array}$ & $\begin{array}{c}\text { GenBank } \\
\text { Accession Number }\end{array}$ & Identity \\
\hline \multirow[t]{4}{*}{ G2 (Population I) } & \multirow[t]{4}{*}{ MT012368 } & $\begin{array}{c}\text { 97.83\% with C. rudolphii B } \\
\text { (JQ071394 }\end{array}$ \\
\hline & & 97.83\% with C. rudolphii B (AJ634783) \\
\hline & & 96.38\% with C. rudolphii A (JQ071415) \\
\hline & & 96.74\% with C. rudolphii $\mathrm{F}(\mathrm{JF} 424597)$ \\
\hline \multirow[t]{4}{*}{ G4 (population I) } & \multirow[t]{4}{*}{ MT308994 } & 97.87\% with C. rudolphii B(JQ071394) \\
\hline & & 97.83\% with C. rudolphii B (AJ634783) \\
\hline & & $96.45 \%$ with $C$. rudolphii A (JQ071415) \\
\hline & & 96.81\% with C. rudolphii F(JF424597) \\
\hline \multirow[t]{3}{*}{ G1 (population II) } & \multirow[t]{3}{*}{ MT012367 } & 98.55\% with C. rudolphii A(JQ071414) \\
\hline & & $\begin{array}{c}\text { 97.83\% with } C \text {. rudolphii B } \\
\text { (AJ634783) }\end{array}$ \\
\hline & & 96.46\% with C. rudolphii $\mathrm{F}(\mathrm{JF} 424597)$ \\
\hline
\end{tabular}


Molecular characterization of Contracaecum rudolphii

\begin{tabular}{|l|l|l|}
\hline G3 (population II) & MT012367 & $98.20 \%$ with C. rudolphii A(JQ071414) \\
\cline { 3 - 3 } & & $97.09 \%$ with C. rudolphii $\mathrm{B}(\mathrm{JQ} 071394)$ \\
& & $96.73 \%$ with C. rudolphii $\mathrm{F}(\mathrm{JF} 424597)$ \\
\hline
\end{tabular}

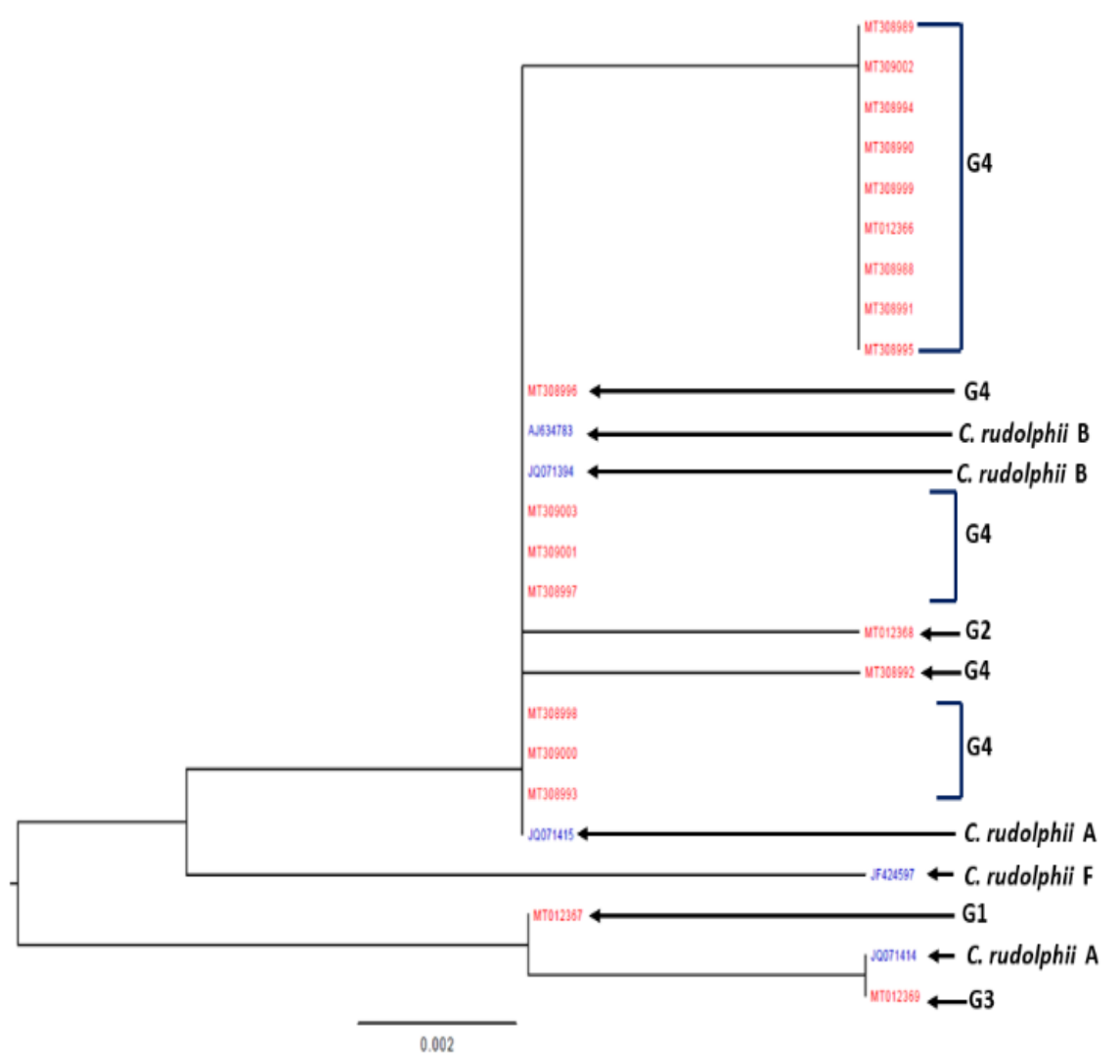

Diagram (2): Phylogenetic tree of the aligned 31 ITS-1 sequences from Contracaecum spp. including 20 ITS-1 sequences of $C$. rudolphii, identified in this study and its relation to published sequences of $C$. rudolphii A, B and F using the PhyML program which is hosted at the http://www.phylogeny.fr/simple_phylogeny.cgi website

\section{DISCUSSION}

The present investigation is the first study to use a genetic approach for the characterization of $C$. rudolphii from nine infected cormorants in central part of Iraq. Based on morphological characteristics, all nematodes collected from cormorants belong to $C$. rudolphii. The $C$. rudolphii showed morphological and morphometric similarities with the same species parasitizing cormorants in the world (Mattiucci et al., 2002; Amato et al., 2006; Moravec and Scholz, 2016); however, morphology and morphometric descriptions are not fully considered in this study because all data regarding microscopic identification has been published before (Al-Moussawi and Mohammad, 2011; Al-Moussawi, 2017). 
The results obtained from the current study revealed four new different genotypes of $C$. rudolphii that were not previously recorded in Iraq. All recorded genotypes showed high percentages of sequence homology with some published ITS-1 genome of $C$. rudolphii, which means that there were few differences between nucleotide sequences of the isolates analyzed in this study and others. These minor differences may be due to the effects of the geographical location or the difference of the host that harbored the parasites (Cole and Viney, 2018). Assuming the enormously extensive range of hosts that are susceptible to C. rudolphii (Torres et al., 2000) and the capability of those hosts to spread broadly, the wide spreading of $C$. rudolphii genotypes and the related low population are likely to be probable. The existence of different genotypes of $C$. rudolphii agreed with the results of Shamsi et al. (2009) who showed that the $C$. rudolphii isolated from P. carbo in Australia revealed the existence of different genotypes. All the sequences of the current study are distributed into two different populations one of them is closely clustered to C. septentrionale isolated from N. nycticorax in Thi-Qar, Iraq (Mohammad and Hbaiel, 2019 a) while the genotypes presence in this population were dispersed, with C. microcephalum isolated from N. nycticorax in Thi-Qar, Iraq (Mohammad and Hbaiel, 2019 a).The sequences of Contracaecum sp. isolated from fish collected from Parishan Lake (Shamsi and Aghazadeh-Meshgi, 2011) and Lake Nasser (Younis et al., 2017) were highly dispersed, and no clear correlations of close clusters were observed with the two populations presented in this current study. The observed close clustered relation and dispersion between the isolates of this study and others are likely to be a function of host differences (bird versus fish) and geographical location.

In this study, some insights have appeared regarding sibling species for the studied population of $C$. rudolphii; the sequences of ITS-1 for the first population had the highest similarity to ITS-1 sequence of $C$. rudolphii B, while the sequences of ITS-1 for the second population had the highest similarity to ITS-1 sequence of $C$. rudolphii A. These results agreed with the results of some previous studies (Mattiucci et al., 2002; Li et al., 2005), who represented that $C$. rudolphii isolated from $P$. carbo included two sibling species nominated C. rudolphii A and C. rudolphii $\mathrm{B}$.

The current study focused on P. carbo and nematodes collected from one area (central part of Iraq). Considering that $C$. rudolphii has been identified at both higher and lower prevalence in other parts of the world (Torres et al., 2000; Dziekońska-Rynko and Rokicki, 2008, Kanarek, 2011), other population genetic structuring from different hosts or in different locations could be expected. This approach however, has significant limitations because it is time consuming and only few numbers of $C$. rudolphii can be collected for microscopic examination. The ITS-1 study therefore will provide an insight regarding genetic divergence of $C$. rudolphii in Iraq. Moreover, the results are likely to support the hypothesis that $C$. rudolphii represents a complex species at least two sibling species.

\section{ACKNOWLEDGMENTS}

Thanks are owed to Dr. Mohammad Al-Maeni, Department of Biology, University of Baghdad, who helped in some genetic analysis of the work.

\section{LITERATURE CITED}

Allouse, B. A. 1961. Birds of Iraq. Vol. 2. Baghdad: Ar-Rabita Press, 279 pp. (In Arabic). 
Al-Moussawi, A. A. 2017. Insights at morphological features of Contracaecum rudolphii Hartwich, 1964 (Nematoda: Anisakidae) as revealed by scanning electron microscope (SEM). Journal of Entomology and Zoological Studies, 5:116-119.

Al-Moussawi, A. A. and Mohammad, M. K. 2011. Contracaecum rudolphii Hartwich, 1964 (Nematoda: Anisakidae) in the cormorant Phalacrocorax carbo (Linnaeus, 1758) wintering in Baghdad area: A new host record in Iraq. Bulletin of the Iraq Natural History Museum, 11(3):7-16.

Amato, J. F., Monteiro, C. M. and Amato, S. B. 2006. Contracaecum rudolphii Hartwich (Nematoda, Anisakidae) from the Neotropical Cormorant, Phalacrocorax brasilianus (Gmelin) (Aves, Phalacrocoracidae) in southern Brazil. Revista Brasileira de Zoologia, 23 (4):1284-1289.

Barrueto, M., Ford, A.T. and Clevenger, A. P. 2014. Anthropogenic effects on activity patterns of wildlife at crossing structures. Ecosphere, 5(3):1-19.

Bartlett, C.M. 1996. Morphogenesis of Contracaecum rudolphii (Nematoda: Ascaridoidea), a parasite of fish-eating birds, in its copepod precursor and fish intermediate hosts. Parasite, 3 (4):367-376.

Bookhout, C. and Greene, K. 2019. Chronic epigastric pain associated with gastric anisakidosis. IDCases, 15:e0515.

Cole, R. and Viney, M. 2018. The population genetics of parasitic nematodes of wild animals. Parasites and Vectors, 11(1):590.

D’Amelio, S., Cavallero, S., Dronen, N.O., Barros, N. B. and Paggi, L. 2012. Two new species of Contracaecum Railliet \& Henry, 1912 (Nematoda: Anisakidae), C. fagerholmi n. sp. and C. rudolphii $\mathrm{F}$ from the brown pelican Pelecanus occidentalis in the northern Gulf of Mexico. Systematic Parasitology, 81(1):1-16.

Daszak, P., Cunningham, A.A. and Hyatt, A.D. 2001. Anthropogenic environmental change and the emergence of infectious diseases in wildlife. Acta Tropica, 78(2):103-116.

Dziekońska-Rynko, J. and Rokicki, J. 2007. Life cycle of the nematode Contracaecum rudolphii Hartwig, 1964 (sensu lato) from northern Poland under laboratory conditions. Helminthologia, 44(3):95-102.

Dziekońska-Rynko, J. and Rokicki, J. 2008. Infestation of the black cormorants (Phalacrocorax carbo sinensis L. 1758) from the colony on the Selment Wielki, with the nematode Contracaecum rudolphii Hartwich, 1964 (Nematoda, Anisakidae). Oceanological and Hydrobiological Studies, 37(4):61-71.

Edgar, R. C. 2004. Muscle: multiple sequence alignment with high accuracy and high throughput. Nucleic Acids Research, 32(5): 1792-1797. 
Guindon, S., Dufayard, J., Lefort, V., Anisimova, M., Hordijk, W. and Gascuel, O. 2010. New algorithms and methods to estimate maximum-likelihood phylogenies: assessing the performance of PhyML 3.0. Systematic Biology, 59 (3):307-321.

Kanarek, G. 2011. Population biology of Contracaecum rudolphii sensu lato (Nematoda) in the great cormorant (Phalacrocorax carbo) from northeastern Poland. Journal of Parasitology, 97(2):185-191.

Li, A-X., D’Amelio, S., Paggi, L., He, F., Gasser, R. B., Lun, Z. R., Abollo, E., Turchetto, M. and Zhu, X-Q. 2005. Genetic evidence for the existence of sibling species within Contracaecum rudolphii (Hartwich, 1964) and the validity of Contracaecum septentrionale (Kreis, 1955) (Nematoda: Anisakidae). Parasitology Research, 96:361-366.

Mattiucci, S., Turchetto, M., Bragantini, F. and Nascetti, G. 2002. On the occurrence of the sibling species of Contracaecum rudolphii complex (Nematoda: Anisakidae) in cormorants (Phalacrocorax carbo sinensis) from Venice and Caorle lagoons: genetic markers and ecological studies. Parassitologia, 44: 105.

Mattiucci, S., Cianchi, R., Nascetti, G., Paggi, L., Sardella, N., Timi, J., Webb, S. C., Bastida, R., Rodr'iguez, D. and Bullini, L. 2003. Genetic evidence for two sibling species within Contracaecum ogmorhini Johnston \& Mawson, 1941 (Nematoda: Anisakidae) from otariid seals of boreal and austral regions. Systematic Parasitology, 54 (1):13-23.

Mohammad, Z. A. A. and Hbaiel, M. K. 2019a. Morphological and Molecular Study of Contracaecum Larvae with a New Record of Contracaecum septentrionale in AlSanaf Marsh Southern Thi-Qar Province, Iraq. Indian Journal of Public Health Research and Development, 10 (10):1271-1276.

Mohammad, Z. A. A. and Hbaiel, M. K. 2019b. Isolate and identify of Contracaecum spp. nematodes from some aquatic bird species by using light microscope and scanning electron microscope. Journal of Education for Pure Science-University of ThiQar, 9(2):180-192.

Moravec, F. 2009. Experimental studies on the development of Contracaecum rudolphii (Nematoda: Anisakidae) in copepod and fish paratenic hosts. Folia Parasitologica, 56 (3):185-193.

Moravec, F. and Scholz, T. 2016. Helminth parasites of the lesser great cormorant Phalacrocorax carbo sinensis from two nesting regions in the Czech Republic. Folia Parasitologica, 63: 022.

Salim, M., Porter, R. and Rubec, C. 2009. A summary of birds recorded in the marshes of southern Iraq, 2005-2008. BioRisk, 3: 205-219. 
Shamsi, S. 2014. Recent advances in our knowledge of Australian anisakid nematodes. International Journal for Parasitology: Parasites and Wildlife, 3(2):178187.

Shamsi, S. 2019. Parasite loss or parasite gain? Story of Contracaecum nematodes in antipodean waters. Parasite Epidemiology and Control, (3):e00087.

Shamsi, S. and Aghazadeh-Meshgi, M. 2011. Morphological and genetic characterisation of selected Contracaecum (Nematoda: Anisakidae) larvae in Iran. Iranian Journal of Fisheries Sciences, 10(2):356-361.

Shamsi, S., Norman, R., Gasser, R. and Beveridge, I. 2009. Genetic and morphological evidences for the existence of sibling species within Contracaecum rudolphii (Hartwich, 1964) (Nematoda: Anisakidae) in Australia. Parasitology Research, 105: 529-538.

Szostakowska, B. and Fagerholm, H-P. 2012. Coexistence and genetic variability of Contracaecum rudolphii A and Contracaecum rudolphii B (Nematoda: Anisakidae) in cormorants, Phalacrocorax carbo sinensis, in the Baltic region. Journal of Parasitology, 98(3):472-478.

Takabayashi, T., Mochizuki, T., Otani, N., Nishiyama, K. and Ishimatsu, S. 2014. Anisakiasis presenting to the ED: clinical manifestations, time course, hematologic tests, computed tomographic findings, and treatment. American Journal of Emergency Medicine, 32 (12):1485-1489.

Torres, P., Valdivieso, J., Schlatter, R., Montefusco, A., Revenga, J., Marín, F., Lamilla J. and Ramallo, G. 2000. Infection by Contracaecum rudolphii (Nematoda: Anisakidae) in the Neotropic cormorant Phalacrocorax brasilianus, and fishes from the estuary of the Valdivia river, Chile. Studies on Neotropical Fauna and Environment, 35(2):101-108.

York, W. and Maplestone, P. A. 1962. The nematode parasites of vertebrates. Haf. Pub. Co., New York, 536 pp.

Younis, A. E., Saad, A. I. and Rabei, J. M. 2017. The occurrence of Contracaecum sp. larvae (Nematoda: Anisakidae) in four teleostean species from Lake Nasser, Egypt: morphological and molecular studies. The Journal of Basic and Applied Zoology, 78:9.

Zhu, X., D'Amelio, S., Paggi, L. and Gasser, R. B. 2000. Assessing sequence variation in the internal transcribed spacers of ribosomal DNA within and among members of the Contracaecum osculatum complex (Nematoda: Ascaridoidea: Anisakidae). Parasitology Research, 86:677-683. 
Bull. Iraq nat. Hist. Mus.

(2020) 16 (2): 135-150.

\section{Contracaecum rudolphii التوصيف الجزيئي للاودة الخيطية} Phalacrocorax carbo المعزول من غراب البحر Hartwich, 1964

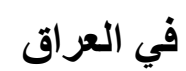

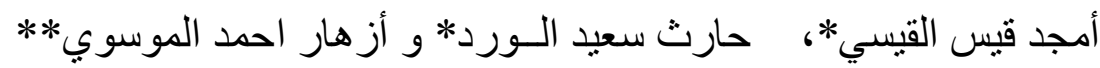

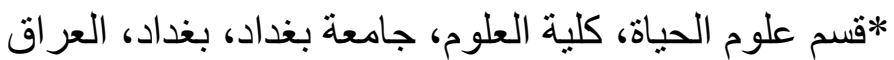

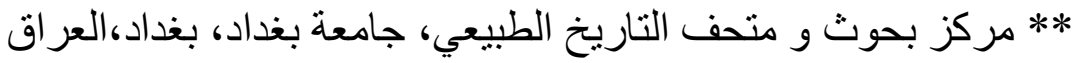
تأريخ الاستلام: 2020/06/22، تأريخ القبول: 2020/08/13، تأريخ النشر: 2020/12/21

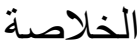

تعد الدودة Contracaecum rudolphii Hartwich, 1964 واحدة من الديدان الخيطية التي تسبب مخاوف كبيرة على صحة الإنسان و الحيو انات البريه. هنالك القليل من الدراسات التي تخص هذا التيات الطفيلي من الناحية الور الثية.

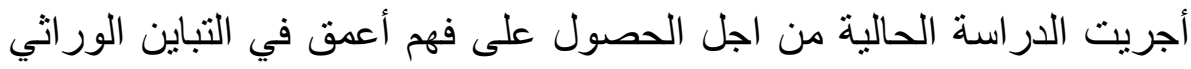

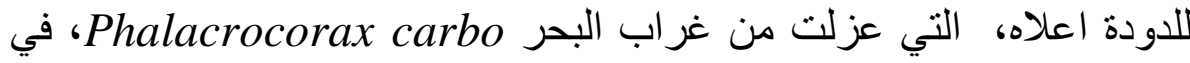

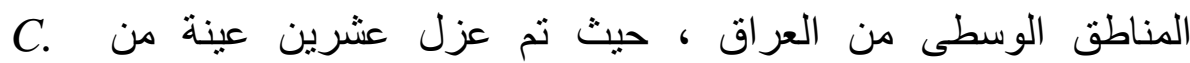
Prudolphii

تم التحري عن الجين (ITS-1) من الدنا الريبوسومي (rDNA) المعزول

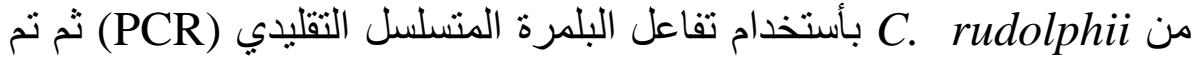

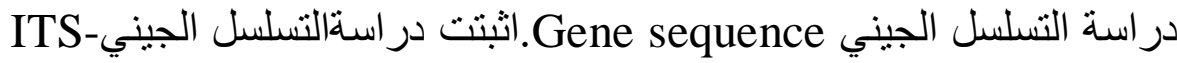
1ظهور أربعة أنماط ور اثية فريدة لم يتم تسجيلها سابقًا في العراق.

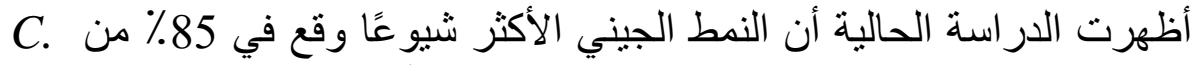

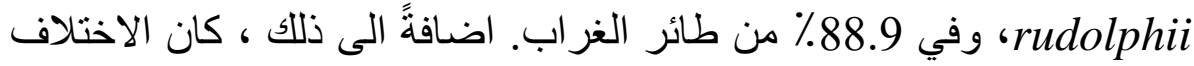

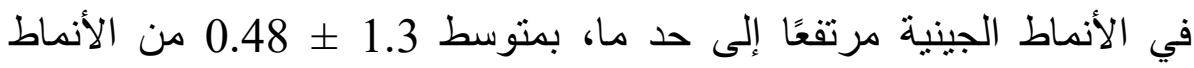
الجينية لكل مجموعة من المضائف المصابة باكثر من دودتين. 
اظهرت نتائج جميع التسلسلات الجينية في هذه الدراسة ظهور مجتمعين

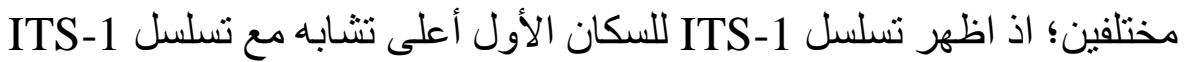
لـ C. rudolphii B، بينما اظهرت تسلسلات ITS-1 للسكان الثاني أعلى الثلى

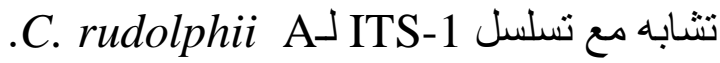

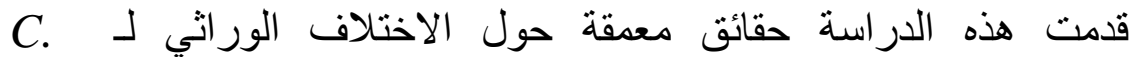
rudolphii الدراسة فرضية كون الديدان الخيطية C. rudolphii تمثل معقدًا من نوعين

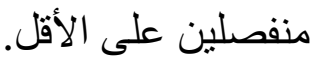

